IOSR Journal of Pharmacy

e-ISSN: 2250-3013, p-ISSN: 2319-4219, www.iosrphr.org

Vol. 3, Issue 1, Jan.-Feb 2013, PP. 13-14

\title{
Clinical Management of Pyometra in Bitches
}

\author{
L. Ramsingh ${ }^{1}$, K. Sadasiva Rao ${ }^{2}$, K.Muralimohan ${ }^{3}$, \\ ${ }^{1,3}$ Assistant Professor, ${ }^{2}$ Professor \& Univ. Head, Dept. of VGO \\ Department of Veterinary Gynaecology\& Obstetrics, College of Veterinary Science, Rajendranagar, \\ Hyderabad - 500030 Sri Venkateswara Veterinary University, ANDHRA PRADESH, INDIA
}

\begin{abstract}
A total 7 (Seven) cases of pyometra of Labrador dogs aged 6-7 years were brought to the College of Veterinary Science, Teaching Veterinary Clinical Hospital, Rajendranagar, Hyderabad, Andhra Pradesh. The history of anorexia, dullness, depression, vomiting, polydysia, poyurea with slight to moderate vulvar discharge since last 3 to 5 days there was no mating of history mating. Pyometra in bitches is polysystemicdiestrual disorder which if not treated can induce high mortality. It is acute or chronic in nature .It is one of the common causes of death in order bitches. Progesterone induce the endometrial hyperplasia usually precedes the development of pyometra. Endometrial thickening is caused by hypertrophy and hyperplasia of endometrial glands which may show secretary activity (Neislon and Feldmen 1986).In pyometra, there is usually nearly complete closures of cervix prevent the escape of mucopurulent and discharges from uterus with a distention of uterus horns. The cases with closed cervix are more toxic than those in which discharges is present (Robert, 1971)
\end{abstract}

\section{Clinical Observation:}

The clinical examination revealed vomiting, polydipsia, polyuria, foul smelling chocolate brown to pinkish vulvar discharge. The four bitches showed high body temperature and rest of the three bitches showed normal body temperature

\section{Diagnosis:}

The definitive of pyometra become very difficult when estrus and breeding history of bitches is not properly known. It may be confused with pregnancy, renal failure, cystitis, vaginal neoplasia and polyarthritis (Christiansen1984). The diagnosis of these cases were made by correlation history, Clinical observation, Hematology, Rectal palpation, abdominal palpation, Radiography, Ultrasonography

\section{Hematology:}

The total leucocyte count (TLC) and differential leucocyte counts (DLC) were studied as per routine clinical procedures (Jain, 1986).The leukocytosis was moderate $\left(16,999-29,999 \mathrm{cells} / \mathrm{mm}^{3}\right)$ in one, marked $\left(29,999-50,000\right.$ cells $\left./ \mathrm{mm}^{3}\right)$ in two and extreme $\left(>75,000\right.$ cells $\left./ \mathrm{mm}^{3}\right)$ in two $80 \%$ in two, marked $(>80-99 \%)$ in four bitches and extreme in (>90\%) in two bitches. In dogs, the normal range of TLC is $6,000-17,000 \mathrm{cells} / \mathrm{mm}^{3}$ while that of neutophila is $60-77 \%$.So moderate to extreme leukocytosis and neutrophilia in these cases may help to diagnosis these cases as pyometra.

\section{Rectal palpation:}

These cases were performed with the help of index finger and revealed that distended and enlarged uterus.

\section{Abdominal palpation:}

Enlarged uterus in four bitches and uterine horn is unclear in one bitch due to tense abdomen. Similar findings were also reported by feldman and Nelson (1987).

\section{Radiography:}

The bitches were fasted overnight and plain radiograph were taken in the lateral recumbent position in the next morning.Radiographically the uterus was seen as fluid dense tubular structure in the ventral and caudal abdomen. Marked uterine enlargement resulting into displacement of intestinal loops was seen in four bitches while lobulated appearance of uterus was in one bitch. (Renton et al. (1991) and Ayyappanet al.(1997) were in observed $100 \%$ visualization of the uterus in pyometra. The present studies also have similar findings.

\section{Ultrasonography:}

The ultrasonography was performed by B-mode, scanner with $7.5 \mathrm{MHZ}$ linear array transducer. A coupling medium (K Y Jelly) was applied on the site to displace air and the uterus was scanned below the 
urinary bladder in the prepubic region. Ultrasonographic was conducted in filled urinary bladder which facilitates imaging of the uterus. Ultrasonographic examination of these cases revealed uterine horn to be 1.5 to $3.2 \mathrm{~cm}$ diameter. Yeager and Concanon (1995) reported that the uterine diameter of $1.0-1.1 \mathrm{~cm}$ along with small amount of fluid is normal during diestrus

Ultrasonographic characteristic of pyometra varied depending upon the extent of involvement and nature of contents. Extensive involvement depicted round hypo echoic to anechoic area, placed side by side covering the complete abdomen while moderate involvement exhibited hypoechoic roughly round structure ventral or ventrolateral to the anechoic urinary bladder in transverse section. Mild involvement was more readilyvisualized on longitudinal section as mixed anechoic to hypoechoic tubular structure.

\section{Treatment and Discussion:}

The cases were treated by injection intacefTazo (Ceftriaxone Sodium and Tazobactum Sodium@20 $\mathrm{mg} / \mathrm{kg}$ body weight for 4-6days ,I/M ,IntacefTazo ${ }^{\mathrm{a}}(565 \mathrm{mg}$ for $4-6$ days intrauterine. Supportive treatment include injection Melonex ${ }^{\mathrm{a}} 2 \mathrm{ml}$ for 3 days $\mathrm{I} / \mathrm{M}$ injection Tribivet vitamin $\mathrm{B}_{1} \mathrm{~B}_{6} \mathrm{~B}_{12}$ and $2 \mathrm{ml}$ for 5 days $\mathrm{I} / \mathrm{M}$ five bitches complete clinical recovery after 4 days of treatment and remaining two bitches showed clinical recovery after 6 days. No reoccurrence of pyometra were reported in cured cases and 6out of 7 bitches conceived when mated subsequently

Haque and Ahmad (2003) reported that the early treatment of pyometra was effective whereas late treatment of pyometra was always fatal.The medical treatment of pyometra with $\mathrm{PGF}_{2}$ alpha is not popular due to its side effects (Wykes and Olson.1993)

The present treatment also showed that intacefTazoboyh I/M, I/U was effective only in early treatment of pyometrasmilar finding with intacef for treatment of pyometra (Sing et al.2008)but ovariohysterctomy is always the choice of trearment (Robert 1971).

\section{REFERENCES}

[1]. Ayyappan,S.,Thilager,S.,Balasubramanian,N.N.and Mohammed, M.S.D.M(1997) Radilogical feature of canine pyometra .indianVeterinary journal 74:1061-62.

[2]. Christiansen ,I.J.(1984) reproduction in the dog and cat.bailliere and Tindall , London,pp 67-71.

[3]. Feldman,E.C.andNelson,R.W.(1987) canine and feline endocrinology and Reproduction.W.B. sanders, Philadelphia.

[4]. Haque,S., and Ahmed, A.(2003) pyometra in the bitches clinical report. Indian journalof veterinary medicine 23:51.

[5]. Jain,N.C.(1986) indianschalms veterinary heamatoligy $4^{\text {th }}$ Edn,Lea and FEbiger ,Philadelphia.

[6]. Renton, J.P.,Douglas, T.A and watts, C.(1971) pyometra in the bitch journal of small animal practices 12:249-54.

[7]. Robert ,S.J.(1971).infertility in bitches and queens .veterinary Obstetrics and genital diseases. ${ }^{\text {nd }}$ Edn .,CAB publisher and Distributors India .,pp.227-36.

[8]. Singh,K.P.Singh,B.,Singh,J.P.andSingh,H.N.(2008) pyometra in bitches Twocase reports intaspolivet 9:99

[9]. Wykes,P.M.and Olson ,P.N.(1993)the diseases mechanics in small Animal Surgery,Edn by M.JosephBojrabLeaandFebiger, Philadelphia,pp.570-73

[10]. Yeager,A.E.andConcannon,P.W.(1995) Ultrasonography of the reproductive trect of the female dog and cat .Indian Kirks current veterinary theraphy XII Small Animal Practice EdnBonagura ,D.andKrikRW.W.B.SaundersCo.philadelphia. 